\title{
The Evolving Role of the Human Rights Factor within the State of Necessity Test in Investment Arbitration
}

\author{
Dmitry V. Krasikov ${ }^{1,2}$ \\ ${ }^{1}$ International Law Department, Saratov State Law Academy, Saratov, Russia \\ ${ }^{2}$ Institute of Scientific Information for Social Sciences of the Russian Academy of Sciences (INION RAN), \\ Moscow, Russia \\ Correspondence: Dmitry V. Krasikov, International Law Department, Saratov State Law Academy, Saratov, \\ 410028, Volskaya 16 - 307, Russia. Tel: 79-1-7207-5730. E-mail: krasikovd@icloud.com
}

Received: October 23, 2019

Accepted: November 22, 2019

Online Published: December 21, 2019

doi:10.5539/jpl.v13n1p12

URL: https://doi.org/10.5539/jpl.v13n1p12

\begin{abstract}
The discussion on increasing the legitimacy of international investment law largely overlooks the potential of the state of necessity, as a circumstance precluding wrongfulness of States' conduct under general international law, for the protection of human rights. The present article deals with the practice of international investment arbitration in cases involving Argentina in connection with its economic crisis of 1998-2001, in which it raised the necessity defense and appealed, inter alia, to human rights. The article concludes that, as a rule, the human rights factor did not play a noticeable role for resolving the relevant disputes. The human rights discourse either had no adequate place within the merits of the disputes, or the tribunals did not take the relevant arguments seriously. The human rights argumentation tried itself within different parts of the Argentina's defense, including various elements of the necessity test, but without meaningful effect. The Award in the case of Urbaser S.A. and Consorcio de Aguas Bilbao Bizkaia, Bilbao Biskaia Ur Partzuergoa v. The Argentine Republic has demonstrated the perspective of recognizing the significance of the human rights factor in the context of "the only way" element of the necessity test: this element can unleash the potential of human rights in the disputes involving the necessity-based defense and provide the tribunals with tools capable of taking human rights more seriously in the context of investment disputes concerning emergencies. The Urbaser Tribunal position is an evidence of the evolving and expanding role of the human rights factor within the necessity test but substantial clarification of this test at the doctrinal, practical and political level is still needed to increase the legitimacy of international investment dispute resolution system.
\end{abstract}

Keywords: state of necessity, human rights, investment arbitration

\section{Introduction}

The issues of legitimacy of international investment law and its dispute settlement system stand among the highly debated topics in international law and politics. The power of international arbitrators to interfere within the internal political space of sovereign States and the limits of this power are being questioned from the standpoint of democracy, rule of law, States' sovereignty and self-determination (Choudhury, 2008; Giest, 2017; Arato, 2019). To overcome these problems, experts propose incorporating human rights and environmental standards into the fabric of international investment law as well as reforming its dispute settlement system as regards the possibility for public interests to play a meaningful role (Giest, 2017; Arcuri \& Montanaro, 2018; Laryea, 2018; Schill \& Djanic, 2018).

Essentially, different ideas for improving and enhancing the legitimacy of international investment law and its mechanisms proceed from the recognition of the need to provide adequate guarantees to the public interests, and some reforms are underway, but they are still insufficient and fragmented (Arcuri \& Montanaro, 2018). Currently, it is believed that public interests are underprotected and at risk.

However, it often goes unnoticed that, in fact, the international law provides a universal tool for protecting States' interests of particular importance that are at risk and raise conflicts with their international obligations, and namely the state of necessity as a circumstance that precludes wrongfulness of a State's conduct under general international law. That is, international law provides States with a possibility to escape international 
responsibility for non-compliance with their international obligations (including those under international investment treaties) when their essential interests (including human rights, environment and other public values) are threatened in a situation of emergency. Accordingly, at least theoretically, a State can, as a defense in the investment disputes, invoke the state of necessity, if it acted to eliminate a threat to public interests.

Nevertheless, this defense is subject to a stringent test and is available only in exceptional circumstances. It is often perceived as a source of a serious risk to the international rule of law rather than as an efficient safeguard for public interests. At the same time, some investment law reform proposals often imply a kind of adaptation of the logic of necessity to the risks stemming from international investment regimes.

Reforms in the investment law field are indeed desirable, but this is a slow and difficult process, while the tool of necessity is already there. In the practice of international arbitration, there are situations when States invoke the state of necessity, and sometimes in the human rights context. However, the defense of necessity is only rarely successful and largely useless, and in those instances when it works, this is usually not due to any human rights concerns.

This article argues that the real reason for insensitivity of the state of necessity standard (as it is perceived by investment arbitral tribunals) towards human rights is not so much the stringency of the necessity test, but its uncertainty, which prevents human rights from influencing within its elements even where there is potential for this. An analysis of investment arbitration practice reveals the evolving and expanding role of the human rights factor within the necessity test but substantial clarification of this test at the doctrinal, practical and political level is still needed to increase the legitimacy of international investment dispute resolution system.

\section{Material Studied, Area Descriptions, Methods and/or Techniques}

A set of emergency legislative measures taken by Argentina to overcome the economic crisis of 1998-2002, spawned a series of international arbitration proceedings initiated by investors from the United States and other States. According to experts, over 40 such proceedings were conducted using arbitration mechanisms established under the 1965 Convention on the Settlement of Investment Disputes between States and Nationals of Other States, as well as under other procedures (Burke-White, 2010). In the context of the present paper, this practice is highly relevant, since one of the lines of Argentina's defense in these cases was to invoke the state of necessity (with reference to the rules of general international law and to the provisions of bilateral investment treaties) to justify its non-compliance with international obligations under relevant treaties.

State of necessity is one of the circumstances precluding wrongfulness of conduct according to general international law. Along with consent, self-defense, countermeasures, force majeure and distress, it was included by the International Law Commission in its 2001 Articles on Responsibility of States for Internationally Wrongful Acts (hereinafter - the ILC Articles). According to Art. 25 of the ILC Articles, "1. Necessity may not be invoked by a State as a ground for precluding the wrongfulness of an act not in conformity with an international obligation of that State unless the act: (a) is the only way for the State to safeguard an essential interest against a grave and imminent peril; and (b) does not seriously impair an essential interest of the State or States towards which the obligation exists, or of the international community as a whole. 2. In any case, necessity may not be invoked by a State as a ground for precluding wrongfulness if: (a) the international obligation in question excludes the possibility of invoking necessity; or (b) the State has contributed to the situation of necessity".

Depending on the position taken by arbitral tribunals when considering cases involving Argentina, regarding precluding wrongfulness of its measures taken to overcome the crisis in economy and social sphere, the corresponding group of cases can be divided into two subgroups. The first (and the larger) one includes cases in which the arbitrators did not upheld the possibility of Argentina to invoke the state of necessity under general international law and under the relevant provisions of bilateral investment agreements to justify its conduct. Among such cases are CMS Gas Transmission Company v. The Republic of Argentina; Enron Corporation and Ponderosa Assets, L.P. v. Argentine Republic; Sempra Energy International v. The Argentine Republic; BG Group Plc. v. The Republic of Argentina; National Grid plc v. The Argentine Republic; Suez, Sociedad General de Aguas de Barcelona, S.A. and Vivendi Universal, S.A. v. Argentine Republic; SAUR International SA v. Republic of Argentina.

The second subgroup includes cases in which the arbitrators sided with Argentina with regard to exempting it from liability by virtue of a reference to the state of necessity. In the $L G \& E$ Energy Corp., LG\&E Capital Corp., $L G \& E$ International, Inc. v. the Argentine Republic the Arbitration Tribunal ruled that "[b]etween 1 December 2001 and 26 April 2003, Argentina was in a state of necessity, for which reason it shall be exempted from the payment of compensation for damages incurred during that period". In the Continental Casualty Company v. The 
Argentine Republic the Tribunal recognized the right of Argentina to rely on the necessity provisions contained in the US-Argentina BIT and dismissed most of the claimant's claims. In the Urbaser S.A. and Consorcio de Aguas Bilbao Bizkaia, Bilbao Biskaia Ur Partzuergoa v. The Argentine Republic, the necessity defense was accepted and largely due to involvement of human rights.

Inconsistency in the case-law under consideration is found not only in the conclusions reached by the arbitrators, but also in the underlying legal arguments (Chubb, 2013). Due to these inconsistencies, this practice has revealed the most problematic issues of the parameters of proper application of customary international law rule on necessity in the investment field.

The cases in which Argentina explicitly referred to human rights in the context of its necessity defense under general international law, stand apart within the group of necessity cases: in the Suez, the Urbaser and the National Grid the tribunals had to deal with the respondent's relevant argumentation, though with different result But in the vast majority of cases Argentina did not raise any arguments directly employing human rights to support its attempt to invoke the state of necessity. Some cases completely miss any reference to human rights (such as the $L G \& E$, the BG Group, the Enron, and the Continental Casualty) (though it is known that, for instance, in the latter case the Respondent raised human rights arguments, but they are not mentioned by the arbitrators (Peterson, 2009)), while others deal with human rights in the context of applicable law (the CMS, the SAUR) or constitutional standards on emergency and necessity (the Sempra). These cases will be discussed below.

\section{Results}

This paper argues that it is not the stringency of the necessity test that prevents human rights to play an influential role in the investment cases concerning emergency circumstances, but the lack of a proper place for the human rights-related arguments within this test due to its uncertainty and absence of a clear and reasonable methodology of its application. An analysis of practice shows that the significance of the human rights factor is evolving within the necessity defense: it started its way from an indistinct place within the framework of applicable law in the CMS, moved on to the context of necessity in the National Grid and the Suez within the "essential interest" element of the necessity test, then reached the criterion of Art. 25(2)(a) of the ILC Articles in the Suez and eventually got to the condition of "the only way" in the Urbaser. This evolution is moving towards finding the right place for the human rights factor and enhancing its role within the necessity defense.

\section{Discussion}

\subsection{Human Rights Issues outside the Necessity Defense}

In the CMS the respondent raised an argument that its Constitution and basic human rights treaties "stand above ordinary treaties such as investment treaties" (the CMS Award, par. 114) and that "as the economic and social crisis that affected the country compromised basic human rights, no investment treaty could prevail as it would be in violation of such constitutionally recognized rights" (ibid.). Addressing this argument, the Tribunal noted: "While treaties in theory could collide with the Constitution, in practice this is not very likely as treaties will be scrutinized in detail by both the Government and Congress $<\ldots>$. In this case, the Tribunal did not find any such collision, firstly, since the Constitution carefully protected the right to property, just as the treaties on human rights did, and, secondly, because there was no question affecting fundamental human rights among the issues disputed by the parties" (ibid., par. 121). Thus, the Tribunal found it easy to avoid human rights discussion, but it seems that it did not take the Respondent's idea quite correctly: while Argentina argued the constitutionally recognized possibility to interfere with the right to property (ibid., par. 113) and the prevalence of those constitutionally and internationally guaranteed human rights, which had been compromised by the crisis, over the rights granted by investment treaties (and impliedly over the individual right to property under its Constitution) (ibid., par. 114), the Tribunal simply pointed at carefulness of protection of the right to property under Constitution and human rights treaties and did not address the issue of relationship between this right and other human rights invoked (in a rather vague manner, though) by the Respondent. Besides, the arbitrators did not explain why the dispute did not involve human rights. Conceivably, for a respondent State in investment arbitration the applicable law is not the best context to confront human rights with the BIT's protection, and even more so using such abstract arguments. As the Urbaser shows, the necessity part of a dispute (if relevant) is a more appropriate place for such discourse. Although one could argue that the $C M S$ has a weaker and a less clear human rights context than that in the Urbaser, this did not prevent Argentina to raise human rights issues at the applicable law stage in a manner that resembles the logic of necessity.

In the Sempra a reference to human rights once again appeared in the context of constitutional discourse but unlike the $C M S$, as a part of the Respondent's justification of its conduct by the "necessity and emergency" 
constitutional standards. The Tribunal admitted that the dispute raised "the complex relationship between investment treaties, emergency and the human rights of both citizens and property owners" in the context of the Argentina's obligations under the Inter-American Convention on Human Rights (the Sempra Award, par. 331332). Although the Tribunal found itself unable to ignore the human rights aspects of the parties' dispute, it stated that "the real issue in the instant case is whether the constitutional order and the survival of the State were imperiled by the crisis, or instead whether the Government still had many tools at its disposal to cope with the situation" (ibid., par. 332). These criteria, which lack a defined source but highly resemble the "essential interest" and "the only way" elements of the necessity test under general international law, were not satisfied, in the Tribunal' view, because "the constitutional order was not on the verge of collapse" and since the "legitimately acquired rights could still have been accommodated" even if the emergency legislation was required (ibid.).

In the SAUR Argentina suggested that as a matter of applicable law the obligations under the 1991 Agreement between the Government of the French Republic and the Government of the Argentine Republic on the reciprocal promotion and protection of investments should be interpreted in harmony with the rules on the protection of human rights and in particular with the human right to water (the $S A U R$ Décision sur la compétence et sur la responsabilité, par. 328). The Tribunal did not reject this contention (ibid., par. 330-332), but this did not play any meaningful role for the outcome of the case.

On the one hand, non-invocation of human rights by Argentina (the opposite is not always evident from the language of the arbitrators' decisions) as a part of its necessity defense under general international law can be considered as an omission on its part. It is hard to deny that the human rights-related concerns are separable from the values and threats related to "the very existence of the State and its independence" (the Enron Award, par. 289), "widespread unemployment and poverty, with dramatic consequences in health, malnutrition and social policies" (ibid.), "health, safety and security of the Argentina State and its people" (the $L G \& E$ Decision on liability, par. 219), "[the State's] economic-financial survival, as well as social and institutional stability" (the $B G$ Group Final award, par. 393), etc. And, as evident by the Urbaser Award, a timely and properly designed human rights-based defense can be fruitful.

On the other hand, the Decision on Liability in the Suez (the case with strong human rights context) shows that invocation of human rights factor may not bring any meaningful result for the respondent. And the cases which omit discussion on human rights in the context of the customary international law rule on necessity, reveal that this factor, even if properly employed by the defense, would likely have been of little influence on the outcome in the light of the arbitrators' approaches towards necessity. An extremely high test for the condition of peril to the State's essential interest (Art. 25(1)(a) of the ILC Articles) (up to the level of a threat to the existence and independence of the State (the Enron Award, par. 306; the Sempra Award, par. 348)), as well as excessively formalistic approaches towards the Art. 25 of the ILC Articles criteria of "the only way for the State to safeguard an essential interest" (the CMS Award, par. 323-324; the Sempra Award, par. 350-351) and of "the State has contributed to the situation of necessity" (the National Grid, par. 262) basically deprive the human rights factor of its potential to strengthen the necessity defense in investment arbitration. And similarly, while those cases, in which Argentina succeeded on the necessity issue, demonstrate alternative ways to interpret the necessity standard, they do not (except the Urbaser) give a clear guidance on how the human rights-related arguments can contribute to the defense.

\subsection{Human Rights Discourse in the Context of Necessity Defense: A Tendency of Change?}

Turning to cases where the human rights factor was more distinctly invoked in the context of the necessity defense shows that the main difficulty in protecting human rights using the state of necessity stems from the lack of a coherent place for human rights in the system of its criteria. This is clearly seen in those cases in which Argentina explicitly referred to human rights in its position on precluding wrongfulness of its conduct.

In the National Grid Argentina put the human rights-based argument in support of its position related to the material breach of the 1990 Agreement between the Government of the United Kingdom of Great Britain and Northern Ireland and the Government of the Argentine Republic for the Promotion and Protection of Investments. As a response to the Claimant's allegation of expropriation of investment, Argentina argued that there was no expropriation either direct or indirect and that its authorities" acts "were legitimate and proportionate regulatory acts of general application adopted in good faith and in order to protect the human rights of the population" (the National Grid Award, par. 136). The Tribunal mostly agreed on these arguments but did not directly address the latter one. In the same case Argentina relied on human rights law on two points related to necessity under customary international law. First, in order to satisfy the "essential interest" element of the necessity test it referred to "the framework of the international law of human rights" in which "the protection of social stability 
and the maintenance of essential services vital to the health and welfare of the population" is recognized as an objective (ibid., par. 245). Second, in order to show its compliance with "the only way" requirement of the necessity test the Respondent tried to find support from the margin of appreciation doctrine developed in the European Court of Human Rights case-law (ibid., par. 247). Basically, Argentina argued that a State faced with a crisis should retain a certain discretion to choose among the options available to address the emergency. These references were not assessed by the Tribunal which found it sufficient and decisive that one (and the only examined) of the necessity criteria - the lack of substantial contribution on the part of the State - was not satisfied (ibid., par. 262).

The relevant part of the Argentina's position in the Suez includes the following line of argumentation: the respective measures were taken by the authorities in order to secure the human right to water; due to the importance of this right for the people's life and health, the water should not be equated with ordinary commodities; when assessing Argentina's compliance with international obligations under the relevant BITs provisions (including the fair and equitable treatment standard), the Tribunal has to grant the Respondent a broader margin of discretion than that in the cases related to ordinary services and has to take into account the context of the Argentina's conduct and the way this context is informed by the right to water (the Suez Decision on Liability, par. 252).

This position was put forward as part of the Argentina's defense of necessity, but it is problematic as to the correlation of its arguments with the elements of the necessity test. While the statements on importance of the human right to water can be considered as implicitly addressing the "essential interest" element, the relevance within the test of the proposition on the margin of discretion is not so evident from the Argentina's position although it has a potential to be linked with "the only way" element. Besides, the Respondent's reference to the material obligations under the BITs (mentioning the fair and equitable treatment provision) shows that it tried to defend prima facie lawfulness of its measures under the BITs rather than argued on precluding wrongfulness of its conduct due to the state of necessity.

It is revealing that the arbitrators could not find an adequate place to evaluate these arguments. The Tribunal's comments on the references to human rights in the Argentina's position and in the amicus curiae submissions appear in the context of assessment of whether the treaty obligation excluded invocation of the state of necessity. The Tribunal's position can be summarized as follows: the Respondent and the amici curiae proceed from the fact that the Argentina's obligations to assure the right to water are somehow superior to its obligations under the bilateral investment treaties, and that the existence of a human right to water also implies giving Argentina the right to take actions in violation of its obligations under such treaties; the Tribunal does not find any support for such approach in the investment treaties or in international law; Argentina has both international human rights obligations and those under the BITs, and must equally comply with both; in the circumstances of the cases under consideration, the obligations of both types are not inconsistent or mutually exclusive (the Suez Decision on Liability, par. 262). This led the Tribunal to conclude that it does not find that any of the relevant investment treaties excludes invocation of the state of necessity, and that therefore, Argentina should be considered as having satisfied the corresponding condition of the reference to the state of necessity.

It is doubtful that the latter condition as well as the Tribunal's conclusion, have anything to do with its argumentation or, more generally, with human rights. If the tribunal had a different view on the coexistence of human rights obligations and those under investment treaties, how could this affect the decision on whether a reference to the state of necessity is excluded by the respective investment obligation? It is indicative that in the relevant part of the Decision the Tribunal, while disagreeing with Argentina and with the amici curiae (speaking in favor of Argentina), concludes in support of the possibility for Argentina to refer to the state of necessity from the standpoint of the corresponding condition (the Suez Decision on Liability, par. 262).

The Argentina's defense in the Urbaser also contained references to human rights in the context of its reliance on the state of necessity, but in contrast with the Suez, the human rights arguments in the Urbaser acquired a clearer role within "the only way" element of the necessity test. Argentina contended that the measures taken at the time of the crisis's peak were the only way to safeguard its essential interests against a grave and imminent peril, and that these measures prevented the human right to water, as well as the right to an adequate standard of living, food and housing, from being adversely affected (the Urbaser Award, par. 702). At the same time, Argentina emphasized that there was no obligation in either domestic or international law that could prevail over Argentina's obligation to guarantee the free and full exercise of the rights of all persons under its jurisdiction (ibid., par. 706). With respect to this defense the Claimants raised two arguments: firstly, they noted that ensuring the human right to water was the responsibility of a State and not of private companies, and secondly, they claimed that Argentina was bound by two types of obligations - on human rights and on protection of foreign 
investments - and therefore the obligation to ensure the human right to water was not an obstacle to the fulfillment of the Respondent's obligations owed to the Claimants (ibid., par. 693-694).

As concerns the first Claimants' argument, at first glance it might seem irrelevant to the state of necessity: the issue of existence or absence of any obligation on the part of a person suffered from an internationally wrongful act does not relate to any of the element of the necessity test and does not refute the Argentina's position on the conflict between the right to water and its obligations towards the Claimants. Nevertheless, the Urbaser Tribunal attached importance to the issues raised by this and the second (which essentially reproduces the position expressed by the Tribunal in the Suez) argument in the context of discussion of whether alternative measures to protect the relevant essential interest were available for Argentina (ibid., par. 716-732). It noted that the question of whether such measures were available had to be considered from a broad perspective as well as from a narrow one. According to the Tribunal, it is necessary to take into account, on the one hand, the needs of Argentina and its population on a national scale, and on the other hand, the situation of the investor. In this regard, the arbitrators did not support the position of the Claimants, as it was focused only on their own interests and did not take into account the national significance of the events in Argentina.

With this assertion, the arbitral tribunal supported the conclusion about the unacceptability of a one-sided, investor-oriented approach to the criterion of "the only way". Assessing the Claimants" argument regarding the coexistence of human rights obligations and those under the investment treaties and the absence of conflict between them, the Tribunal notes that this argument is "too short" and it does not resolve the contradiction between the obligation to guarantee the concessionaire's right to concession and the access of poor and vulnerable people to water when this access cannot be provided otherwise than by the State's failure to fulfill its obligations with respect to the concessionaire (ibid., par. 720).

Thus, the arbitrators raised a question that the arbitrators in the Suez did not get to - what would happen if a conflict really exists? An answer to this question requires a certain test of balancing of interests and it evidently relates to the issue of the State's margin of discretion. In the earlier cases the tribunals found it easy to pass by the Argentina' arguments on its human rights obligations, referring to their presumed compatibility with obligations in the investment field, but the way the issue was raised in the Urbaser makes it more difficult as it requires certain balancing tools.

The Tribunal's position in the Urbaser as regards this part of the dispute can be seen as evident of a progress towards expanding the role of the human rights factor within the necessity test in investment arbitration: while earlier the human rights-related arguments within the necessity defense were assessed in the context of the "essential interest" criterion (the National Grid) and (less persuasively) for the purpose of assessment of whether the investment obligations exclude invocation of necessity (the Suez), the Urbaser Tribunal touched upon them in connection with "the only way" element of the necessity test.

\section{Conclusion}

The situations of emergency such as that of the Argentina's economic crisis in 1998-2002, inevitably affect human rights. The general international law rule on the state of necessity allows a State acting to protect its essential interests to be excused from responsibility for departure from its international obligations, and theoretically has a potential to protect human rights in emergent circumstances. At the same time, as shown by the practice of investment arbitration, this potential is poorly if at all realized. The human rights discourse either has no adequate place within the merits of the disputes, or the tribunals do not take relevant arguments seriously. The human rights argumentation has tried itself within different parts of Argentina's defense, including various elements of the necessity test, but in most cases it did not have any meaningful impact on dispute resolution. The Award in the case of Urbaser has demonstrated the perspective of recognizing the significance of the human rights factor in the context of "the only way" element of the necessity test: this element can unleash the potential of human rights in the disputes involving the necessity-based defense and provide the tribunals with tools capable of taking human rights more seriously in the context of investment disputes concerning emergencies.

\section{Acknowledgements}

The present paper is a part of a larger project "Circumstances precluding wrongfulness of conduct: the analysis of functional role and applicability parameters in the framework of International Human Rights Law" supported by the Russian Foundation for Basic Research (RFBR Grant No. 18-011-00660).

\section{References}

Arato, J. (2019). The private law critique of international investment law. The American Journal of International Law, 113(1), 1-53. https://doi.org/10.1017/ajil.2018.96 
Arcuri, A., \& Montanaro, F. (2018). Justice for all? Protecting the public interest in investment treaties. Boston College Law Review, 59(8), 2791-2824.

Burke-White, W. W. (2010). The Argentine financial crisis: State liability under BITs and the legitimacy of the ICSID system. In M. Waibel, A. Kaushal, K.-H. Chung, \& C. Balchin (Eds.), The backlash against investment arbitration: Perceptions and reality (pp. 407-432). Alphen aan den Rijn, NL: Kluwer Law International.

Choudhury, B. (2008). Recapturing public power: Is investment arbitration's engagement of the public interest contributing to the democratic deficit? Vanderbilt Journal of Transnational Law, 41(3), 775-832.

Chubb, K. (2013). The "state of necessity" defense: A burden, not a blessing to the international investment arbitration system. Cardozo J. of Conflict Resolution, 14(2), 531-556.

Giest, A. (2017). Interpreting public interest provisions in international investment treaties. Chicago Journal of International Law, 18(1), 321-352.

Laryea, E. T. (2018). Making investment arbitration work for all: addressing the deficits in access to remedy for wronged host state citizens through investment arbitration. Boston College Law Review, 59(8), 2845-2875.

Peterson, L. E. (2009). Human rights and bilateral investment treaties: Mapping the role of human rights law within investor-state arbitration. Quebec, Canada: Rights \& Democracy (International Centre for Human Rights and Democratic Development).

Schill, S. W., \& Djanic, V. (2018). Wherefore art thou? Towards a public interest-based justification of international investment law. ICSID Review, 33(1), 29-55. https://doi.org/10.1093/icsidreview/six025

\section{Copyrights}

Copyright for this article is retained by the author(s), with first publication rights granted to the journal.

This is an open-access article distributed under the terms and conditions of the Creative Commons Attribution license (http://creativecommons.org/licenses/by/4.0/). 